\title{
The first record of Cooksonia from South America in Silurian rocks of Bolivia
}

\author{
E. MOREL*, D. EDWARDS $\dagger \&$ M. IÑIGEZ RODRIGUEZ \\ * Department of Palaeobotany, La Plata Museum, Paseo del Bosque s/m, 1900 La Plata, Argentina \\ $\dagger$ Department of Earth Sciences, University of Wales Cardiff, P.O. Box 914, Cardiff CFI 3YE, UK \\ $\ddagger$ C.I.G. Calle 1 No. 644,1900 La Plata, Argentina
}

(Received 5 January 1995; accepted 4 April 1995)

\begin{abstract}
Plant megafossils resembling Cooksonia caledonica Lang are described from the Kirusillas Formation in southern Bolivia. Faunal and lithological evidence together with field relationships advocate a late Silurian (Ludlow) age. Palaeocontinental reconstructions suggest that the plants grew on the western edge of Gondwana at $50-60^{\circ} \mathrm{S}$ and indicate that Cooksonia had spread to higher latitudes soon after its appearance in the Wenlock.
\end{abstract}

\section{Introduction}

Megafossils of Silurian land plants are rare and, except for the Australian Baragwanathia assemblage (Garratt et al. 1984), usually found in the northern hemisphere (Edwards, 1990a, $b$; Richardson \& Edwards, 1989). Here we report on an unequivocally fertile rhyniophytoid (sensu Edwards \& Edwards, 1986) from southern Bolivia, which provides insight into land vegetation at high latitudes on the west of the largest Silurian palaeocontinent, Gondwana, in late Silurian times. Plants were first recorded in the area near Tarija by Petriella \& Súarez-Soruco (1989) who illustrated by line drawings, smooth, bifurcating axes assignable to Hostinella, some with elongate swollen terminations. These were compared with Steganotheca Edwards (1970) although they lacked all the major diagnostic characters of that genus. The new fossils have more convincing sporangia, which are short, wide and terminate naked isotomously branching axes.

\section{Locality and description}

The specimen was collected from an otherwise almost barren yellow-grey siltstone interbedded with thin blocky sandstones of the Kirusillas Formation (Ahlfeld \& Branisa, 1960), exposed on the steep north side of a gully formed by the Jarcas stream. Abundant fragmentary sterile axes also occur in more micaceous siltstones $3-4 \mathrm{~m}$ below. The locality is $c .500 \mathrm{~m}$ northeast of Negra Muerta Farm, c. $30 \mathrm{~km}$ northeast of Tarija and some $8 \mathrm{~km}$ east of San Lorenzo (Fig. 1). The plants are coalified compressions, although most of the organic matter has been destroyed revealing dark staining in the matrix beneath. The most complete specimen, $12.5 \mathrm{~mm}$ long, has two branch points and three attached terminal sporangia of very uniform size (Fig. 2).
Branching is isotomous. Between bifurcations the naked axes are parallel-sided when complete and range between $0.5 \mathrm{~mm}$ in diameter proximally and $0.3 \mathrm{~mm}$ distally. There is a gradual widening below a sporangium such that the limits of sporangium and axis are difficult to determine (Fig. 2b). Sporangial height is thus estimated at $c .1 .3 \mathrm{~mm}$. Two further sporangia and axes lie alongside. All sporangia are $1.5 \mathrm{~mm}$ wide and possess a narrow, but well-defined border $(0.12 \mathrm{~mm}$ maximum width) around the convex margin. Spores were not recovered.

\section{Identity of specimen}

As defined by Lang (1937), the fossils belong to Cooksonia. Sporangial shape and border suggest closest affinity with Lochkovian C. caledonica Edwards (1970) although the curved junction between sporangium and axis has not been observed. The Prídolí Xinjiang/Kazakhstanian terminal sporangia (Junggaria/Cooksonella) have much wider borders with a different outline and terminate axes with occasional spines (Cai, Dou \& Edwards, 1993) while the much larger C. crassiparietilis from Kazakhstanian Lower Devonian is better placed in a new genus (Yurina, 1969; Edwards \& Edwards, 1986). The specimen may represent a lateral branching unit of a pseudomonopodial system as in Renalia (Gensel, 1976; Fanning, Edwards \& Richardson, 1992), although such branching patterns are not recorded at the locality.

There are problems with unconditional assignation of the Bolivian specimen to $C$. caledonica, the latter being based on impression fossils. Certain Welsh Borderland Lochkovian sporangia have a narrow border and reniform outline reminiscent of C. caledonica, but on spore characteristics and mode of dehiscence they are unlike any other cooksonias and require a new genus. Thus, until more information becomes available on the Bolivian plant, it is better named $C$. cf caledonica.

\section{Correlation and age determination}

The Kirusillas Formation (Ahlfeld \& Branisa, 1960) at the Negra Muerta locality is identified by its lithology. Elsewhere in the same region, it is underlain ?unconformably by the Cancañiri Formation, the local equivalent of the Zapla Formation to the south in Argentina and also known as the Sacta Formation in Bolivia (Branisa et al. 1972). The overlying 


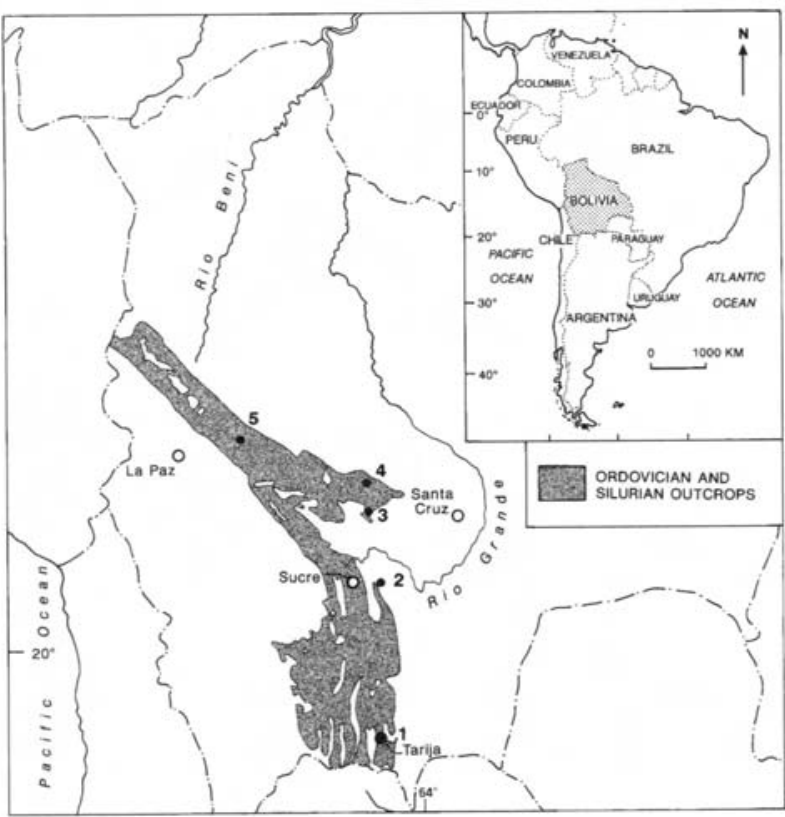

Figure 1. Ordovician and Silurian outcrops in Bolivia with localities mentioned in text. 1 = Negra Muerta locality, with Silurian plants; 2 = Tarabuco; $3=$ Kirusillas; $4=$ Pojo; $5=$ Lampaya. Redrawn from Ahlfeld \& Branisa (1960).

Tarabuco Formation, again recognized by its lithology, outcrops in the hillside to the south of the Jarcas stream nearer the farm. Elsewhere the Kirusillas Formation passes conformably into the Tarabuco Formation which in certain areas is replaced by the lateral equivalent, the Santa Rosa Group (Berry \& Boucot, 1972). Interpreting the geology of this little-studied area is thus confounded by lateral changes in facies, the variety of names applied to the diachronous units and a dearth of fossils. However, the fossils were undoubtedly found in the Kirusillas Formation whose age is constrained by fossils in overlying and underlying formations and by fossils in the Kirusillas Formation itself elsewhere.

The Cancañiri Formation was recently described as Ashgill on the basis of brachiopods found near Cochabamba in rocks of similar and distinctive lithology (Benedetto, Sanchez \& Brussa, 1992) although Berry \& Boucot (1972) assigned it a Llandovery age. Crowell, Súarez-Soruco \& Rocha-Campos (1981) placed it in the Wenlock on evidence from Duvernaysphaera jelinii Zone acritarchs and chitinozoans.

The lower part of the Kirusillas Formation in the Pojo and Lampaya regions, c. $260 \mathrm{~km}$ north and $450 \mathrm{~km}$ northwest of Tarija, contains upper Ludlow-Přídolí acritarchs (Lobo, SúarezRiglos \& Súarez-Soruco, 1976). In the same area, but in different sections, early Ludlow graptolites are recorded (Cuerda \& Antelo, 1973). This age determination is consistent both with one based on brachiopods from exposures to the west of Tarabuco (Racheboeuf \& Branisa, 1985; Benedetto, Sanchez \& Brussa, 1992) and on brachiopods and graptolites (Davila \& Rodriguez, 1967). In summarizing all palaeontological evidence, Berry \& Boucot (1972) proposed a late Llandovery to early Devonian age range in the Pojo area (the early Devonian palynomorphs occurring in the top $150 \mathrm{~m}$ ) and a late Llandovery into Wenlock or Ludlow age elsewhere, including the Tarija area (Fig. 1). Benedetto, Sanchez \& Brussa (1992) concluded that the overlying Tarabuco Formation ranged from Ludlow into Prídolí based on brachiopod evidence from the Lampaya and Tarabuco regions (Lopez Pugliessi \& Lopez

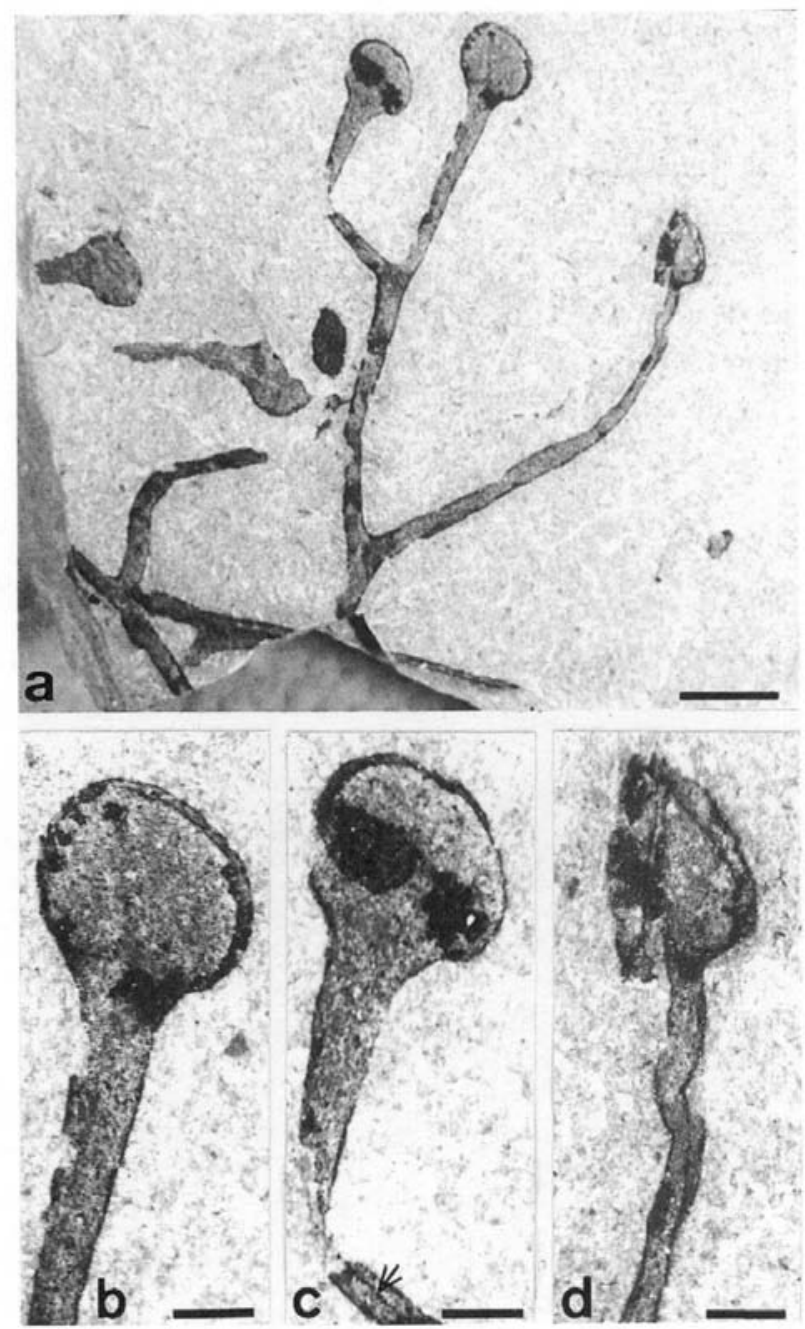

Figure 2. Cooksonia cf caledonica, Tarija, southern Bolivia. LPPB 12744. (a) View of entire specimen, including two isolated terminal sporangia. Scale bar $=2.1 \mathrm{~mm}$. (b-d) Sporangia, showing marginal band; sporangium in (d) is folded. Note possible central strand (arrowed) in (c). Scale bars $=0.5 \mathrm{~mm}$.

Murillo, 1975), although McGregor (1984) had reported a spore assemblage of Lower Devonian aspect and a Přídolí/Gedinnian one from the older. Chitinozoans recovered from the uppermost Kirusillas Formation and base of the Tarabuco Formation to the west of Tarabuco are typical of the Pridolí (Racheboeuf $e t$ al. 1993). Collectively such data suggest that in the Tarija area, the Kirusillas Formation was deposited in post-Llandovery to prePrídolí time and that the fossils are probably of Ludlow age.

\section{Palaeogeography}

Of the considerable number of palaeocontinental reconstructions for the late Silurian (e.g. Van der Voo, 1988; Scotese \& Barrett, Bachtase \& Briden and Boucot in McKerrow \& Scotese, 1990; Cocks \& Scotese, 1991) we chose the base-map of Denham \& Scotese (1987), because it shows a polar projection extending to the equator (Fig. 3). The Bolivian locality is between $50^{\circ} \mathrm{S}$ and $60^{\circ} \mathrm{S}$ on the edge of the Gondwana land mass.

As the pole occurs more or less centrally on the latter, glaciation would have been at a minimum (see models of Crowley, Mengel \& Short, 1987), while precipitation would have been 


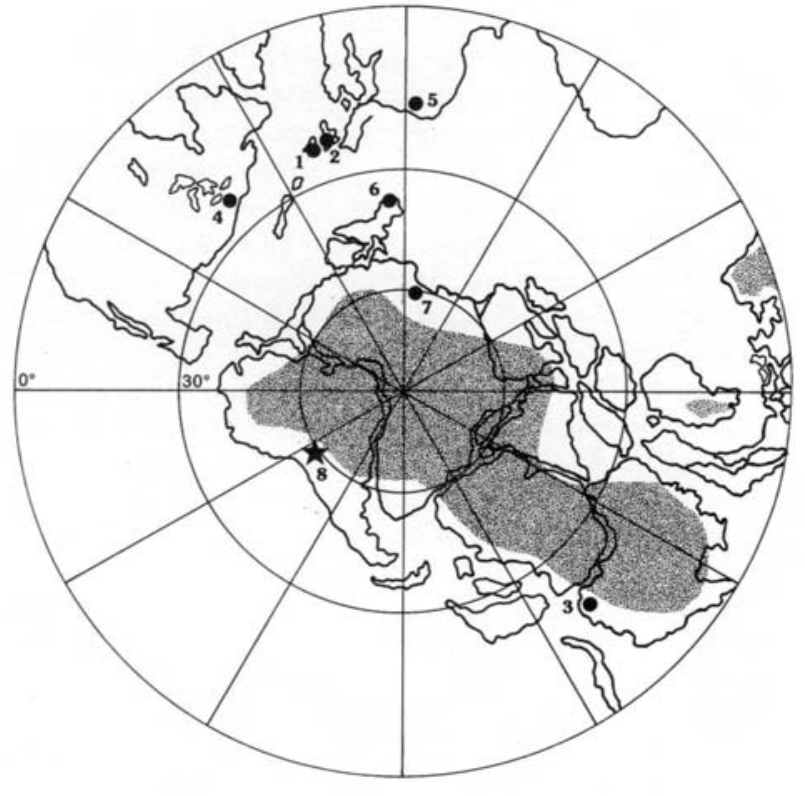

Figure 3. Distribution of plant megafossil assemblages in the late Silurian southern hemisphere. Land areas stippled. 1: Wenlock, Ireland; 2: Ludlow-Př́dolí, southern Britain; 3: Ludlow, Australia; 4: Př́́dolí, New York State; 5: Př́dolí, Podolia; 6: PY̌ídolí, Bohemia; 7: Př́dolí, Libya; 8: Tarija. Localities in Greenland, Siberia, Kazakhstan and Xinjiang are in the Silurian northern hemisphere. Locality details in Edwards (1990b); continental positions based on Denham \& Scotese (1987).

high throughout the year (Parrish, 1990). The sediments of the Kirusillas Formation offer little information on palaeoclimate, unlike the diamictites of the Cancañiri (Zapla) Formation. Originally interpreted as true marine tillites (Rodrigo, Castaños \& Carrasco, 1977) these are now considered turbidites (Bossi \& Viramonte, 1975), although continental mountain glaciers may well have contributed significantly to the sources of sediment (Hambrey, 1985). However, the faunas at the base of the Kirusillas Formation (Upper Llandovery), preserved in a progradational delta system, are typical of Malvinokaffric assemblages. The siltstones and sandstones derive from an early Palaeozoic land mass to the west, presumably the sites of the growth of the plants (Andreis et al. 1982; Böttcher et al. 1984). The excellent preservation of the specimen described here suggests minimal transport.

\section{Significance of the new find}

This is the first record of a Silurian land plant with unequivocal sporangia in South America and only the fourth Silurian record from Gondwana (Daber, 1971; Př́dolí of Libya; Obrhel, 1962: Přidolí of Bohemia). On admittedly very limited evidence, the plant has more in common as regards level of organization with those of the northern hemisphere than with the Baragwanathiadominated assemblages from coeval sediments in Australia, at lower latitudes in the Silurian southern hemisphere (Fig. 3). Euramerican Ludlow assemblages are rare (Richardson \& Edwards, 1989) and less diverse than Prídolí ones. The most extensive (Capel Horeb, South Wales: Ludfordian (Whitcliffe) rocks) contains Steganotheca and several types of Cooksonia. One isolated sporangium (Edwards \& Rogerson, 1979; pl. Id.) shares a border and sporangial outline with the Bolivian speci- men and was also named $C$. cf caledonica. The new data from Bolivia indicate the widespread geographical distribution of Cooksonia, including its spread into higher latitudes soon after its appearance in the Wenlock (Edwards, Feehan \& Smith, 1983). Finally, this discovery, together with numerous sterile axes from Negra Muerta and fossils from a second locality at Padcaya, south of Tarija, demonstrates the great potential of Bolivia for discovering more about global Silurian land vegetation.

Acknowledgement. The project is financed by EC Contract $\mathrm{CI} 1{ }^{*}$-CT92-0054 which is gratefully acknowledged. This paper is dedicated to the memory of Drs B. Petriella and O. G. Arrondo.

\section{References}

Ahlfeld, F. \& Branisa, L. 1960. Geología de Bolivia. La Paz: Instituto Boliviano del Petroleo. 245 pp.

ANDreis, R. R., BötTCher, G. M., Frigerio, M. L., Hinterwimmer, G. A. \& SAmosiuk, N. B. 1982. Interpretación paleoambiental de la secuencia paleozoica aflorante en el Rio Grande, Sierra de Zapla, Jujuy, Argentina, y consideraciones sobre su edad. Quinto Congreso Latinoamericano de Geologia, Argentina, 1982. Actas II, 457-79.

Benedetto, J.-L., Sanchez, T. M. \& Brussa, E. D. 1992. Las Cuencas Silúricas de América Latina. In Paleozoico Inferior de Ibero-América (eds J. C. Gutiérrez-Marco, J. Saavedra and I. Rábano), pp. 119-148. Universidad de Extremadura.

BerRY, W. B. N. \& Boucot, A. J. 1972. Correlation of the South American Silurian rocks. Geological Society of America, Special Paper 133.

Bossi, G. E. \& ViRamonte, J. G. 1975. Contribución al conocimiento de la petrología de los yacimientos ferríferos sedimentarios de Zapla y Unchimé (provincias de Jujuy y Salta, Rep. Argentina). II Congreso Ibero-Americano de Geologia Económica 5.

Böttcher, G., Frigerio, M., Samosiuk, N. \& Vistalli, M. C. 1984. Modelo paleoambiental para la sedimentación de las unidades precarbónicas (Siluro-Devónicas) en al subsuelo de la cuenca Paleozoica del noroeste. Noveno Congreso Geologico Argentino, S.C. de Bariloche, 1984. Actas V, 87-92.

Branisa, L., Chamot, G., Berry, W. B. N. \& Boucơ, A. J. 1972. Silurian of Bolivia. In Correlation of the South American Silurian Rocks (eds W. B. N. Berry and A. J. Boucot), pp. 21-31. Geological Society of America, Special Paper no. 133.

Cai Chong-Yang, Dou Ya-Wei \& Edwards, D. 1993. New observations on a Prídolí plant assemblage from north Xinjiang, northwest China, with comments on its evolutionary and palaeogeographical significance. Geological Magazine 130, 155-70.

Cocks, L. R. M. \& SCOTESE, C. R. 1991. The global biogeography of the Silurian Period. In The Murchison Symposium. Proceedings of an intermational conference on the Silurian System (eds M. G. Bassett, P. D. Lane and D. Edwards), pp. 109-122. Special Papers in Palaeontology no. 44.

Crowell, J. C., Súarez-Soruco, R. \& Rocha-Campos, A. C. 1981. The Silurian Cancañiri (Zapla) Formation of Bolivia, Argentina and Peru. In Earth's pre-Pleistocene glacial record (eds M. J. Hambrey and W. B. Harland), pp. 902-907. Cambridge: Cambridge University Press.

Crowley, T. J., Mengel, J. G. \& ShorT, D. A. 1987. Gondwanaland's seasonal cycle. Nature 329, 803-807. 
Cuerda, A. J. \& ANTelo, B. 1973. El limite Silúrico-Devónico en los Andes Centrales y Orientales de Bolivia. V Congreso Geológico Argentino, Córdoba, 1973. Actas III, 183-96.

DABER, R. 1971. Cooksonia - one of the most ancient psilophytes - widely distributed, but rare. Botanique (Nagpur) 2, 35-40.

Davila, J. \& Rodriguez, E. 1967. The Devonian System in Bolivia and the problem of its base. In International Symposium on the Devonian System, Calgary, 1967, Volume II (ed. D. H. Oswald), pp. 921-35. Calgary: Alberta Society of Petroleum Geologists.

Denham, C. R. \& SCOTESE, C. R. 1987. "Terra Mobilis": a plate tectonics program for the Macintosh. Earth in Motion Technologies, PO Box 49245, Austin, Texas 78765.

EDWARDS, D. 1970. Fertile Rhyniophytina from the Lower Devonian of Britain. Palaeontology 13, 451-61.

EDWARDS, D. 1990a. Silurian-Devonian paleobotany: problems, progress and potential. In Antarctic paleobiology. Its role in the reconstruction of Gondwana (eds $\mathrm{T}$. N. Taylor and E. L. Taylor), pp. 89-101. New York: Springer-Verlag.

EDWARDS, D. 1990b. Constraints on Silurian and Early Devonian phytogeographic analysis based on megafossils. In Palaeozoic palaeogeography and biogeography (eds W. S. McKerrow and C. R. Scotese), pp. 233-242. The Geological Society of London, Memoir no. 12.

EDWARDS, D. \& EDWARDS, D. S. 1986. A reconsideration of the Rhyniophytina, Banks. In Systematic and taxonomic approaches in palaeobotany (eds R. A. Spicer and B. A. Thomas), pp. 199-220. The Systematics Association Special Volume no. 31. Oxford: Clarendon Press.

EDWARDS, D. \& Rogerson, E. C. W. 1979. New records of fertile Rhyniophytina from the late Silurian of Wales. Geological Magazine 116, 93-98.

Edwards, D., FeEhan, J. \& SMITH, D. G. 1983. A late Wenlock flora from Co. Tipperary, Ireland. Botanical Journal of the Linnean Society 86, 19-36.

Fanning, U., Edwards, D. \& Richardson, J. B. 1992. A diverse assemblage of early land plants from the Lower Devonian of the Welsh Borderland. Botanical Journal of the Linnean Society 109, 161-88.

Garratt, M. J., Tims, J. D., Rickards, R. B., Chambers, T. C. \& DOUGLAS, J.G. 1984. The appearance of Baragwanathia (Lycophytina) in the Silurian. Botanical Journal of the Linnean Society 89, 355-58.

GENSEL, P. G. 1976. Renalia hueberi, a new plant from the Lower Devonian of Gaspé. Review of Palaeobotany and Palynology 22, 19-37.

HAMBREY, M. J. 1985. The Late Ordovician-Early Silurian glacial period. Palaeogeography, Palaeoclimatology, Palaeoecology 51, 273-89.

LANG, W. H. 1937. On the plant-remains from the Downtonian of England and Wales. Philosophical Transactions of the Royal Society of London, Series B 227, 245-91.

Lobo, J., Súarez-Riglos, M. \& Súarez-Soruco, R. 1976. Nuevas unidades cronoestratigráficas para el Paleozoico medio de la Provincia Austral Sudamericana. V Convención Nacional de Geología Potosi, Bolivia.

Lopez Pugliessi, J. M. \& LOPEZ MuRILlo, R. D. 1975. Estratigrafía de los Sistemas Silúrico y Devónico de Bolivia. Revista Técnica de YPFB (Yacimentos Petroliferos Fiscales Bolivianos) 4, 233-64.

MCGREgoR, D. C. 1984. Late Silurian and Devonian spores from Bolivia. Córdoba, Argentina, Academica Nacional de Ciencias, Miscelanea no. 69.

MCKerrow, W. S. \& SCOTESE, C. R. 1990. Palaeozoic palaeogeography and biogeography. The Geological Society of London, Memoir no. 12.

OBrhel, J. 1962. Die Flora der Př́dolí-Schichten (BudnanyStufe) des mittelböhmischen Silurs. Geologie 11, 83-97.

PARRISH, J. T. 1990. Gondwanan paleogeography and paleoclimatology. In Antarctic paleobiology. Its role in the reconstruction of Gondwana (eds T. N. Taylor and E. L. Taylor), pp. 15-26. New York: Springer-Verlag.

Petriella, B. \& Súarez-SoRuCo, R. 1989. Presencia de plantas terrestres, probablemente vasculares, en las formaciones Kirusillas y Tarabuco (Lampayano-Silúrico Superior) de Bolivia. Revista Técnica de YPFB (Yacimentos Petroliferos Fiscales Bolivianos) 10, 119-21.

Racheboeuf, P. R. \& Branisa, L. 1985. New data on Silurian and Devonian chonetacean brachiopods from Bolivia. Journal of Paleontology 59, 1426-50.

Racheboeuf, P. R., Le Herisse, A., Paris, F., Babin, C., GuIllocheau, F. \& TruYOLS-MASSONI, M. 1993. El Devónico de Bolivia: bio y chroneostratigrafía. Bulletin Institut français études andines 22, 645-55.

RichaRdSON, J.B. \& EDWARDS, D. 1989. Sporomorphs and plant megafossils. In A global standard for the Silurian system (eds C. H. Holland and M. G. Bassett), pp. 216-26. National Museum of Wales Geological Series no. 9, Cardiff.

Rodrigo, L. A., Castaños, A. \& Carrasco, R. 1977. La Formación Cancañiri, sedimentología y paleogeografía. Revista de Geociencia, University Mayor de San Andrés, La Paz, Bolivia 1, 1-22.

VAN DER VOo, R. 1988. Paleozoic paleogeography of North America, Gondwana, and intervening displaced terranes: comparisons of paleomagnetism with paleoclimatology and biogeographical patterns. Bulletin of the Geological Society of America 100, 311-24.

YURINA, A. L. 1969. Devonian floras of central Kazakhstan. Materiely po geologii Shentral 'nogo Kazakhstana 8, 1-208. 